\title{
Facility Contact Backup
}

National Cancer Institute

\section{Source}

National Cancer Institute. Facility Contact Backup. NCI Thesaurus. Code C127529.

The secondary contact person at a facility. 